\title{
Effecte of NPK Fertigation Rate and Starter Fertilizer on the Growth and Yield of Cucumber Grown in Greenhouse
}

\author{
Mostafa Nabawy Feleafel ${ }^{1,2}$, Zohair Mahmoud Mirdad ${ }^{1} \&$ Abdishakur Sheikh Hassan ${ }^{1}$ \\ ${ }^{1}$ Department of Arid Land Agriculture, Faculty of Meteorology, Environment, and Arid Land Agriculture, King \\ Abdulaziz University, Saudi Arabia \\ ${ }^{2}$ Department of Vegetable Crops, Faculty of Agriculture, Alexandria University, Alexandria, Egypt \\ Correspondence: Mostafa Nabawy Feleafel, Department of Arid Land Agriculture, Faculty of Meteorology, \\ Environment, and Arid Land Agriculture, King Abdulaziz University, Saudi Arabia. E-mail: \\ most363@gmail.com
}

Received: June 3, 2014 Accepted: June 26, 2014 Online Published: August 15, 2014

doi:10.5539/jas.v6n9p81 URL: http://dx.doi.org/10.5539/jas.v6n9p81

\begin{abstract}
Two greenhouse experiments were conducted at Agricultural Research Station, Hada-Alsham, King Abdulaziz University, Saudi Arabia. To study the effects of the four NPK fertigation rates $(50 \%, 75 \%, 100 \%$ and $125 \%$ of recommended; $220,150,150 \mathrm{~kg} \mathrm{~N}, \mathrm{P}_{2} \mathrm{O}_{5}, \mathrm{~K}_{2} \mathrm{O} /$ ha, respectively) and three starter fertilizers ( $\mathrm{SF}$ ); $\mathrm{SF}_{0}$ (control), $\mathrm{SF}_{2}$ : 7-14-7 and $\mathrm{SF}_{3}$ : 7-28-7 kg N- $\mathrm{P}_{2} \mathrm{O}_{5}, \mathrm{~K}_{2} \mathrm{O} / \mathrm{ha}$, on the growth, yield, and minerals contents of cucumber plants, cv. Alrased $92 \mathrm{~F}_{1}$. The results indicated that application of NPK fertigation up rate $125 \%$ of recommended, achieved significant increases in the plant height and number of leaves at (30,50 and 70 DAS), number of branches at 30 DAS only, as well as leaf minerals (N, P and K) contents, fruit setting percentage, fruit weight, number of fruits and fruits yield. Cucumber plants receiving starter fertilizers achieved an increase in the plant height, number of leaves and branches, especially at early growth stages (30 and $50 \mathrm{DAS})$. Likewise, $\mathrm{SF}_{2}(7-28-7$ $\mathrm{kg} \mathrm{N}-\mathrm{P}_{2} \mathrm{O}_{5}-\mathrm{K}_{2} \mathrm{O} /$ ha) recorded significant maximum increment in the all tested fruit yield characters. Moreover, soil application of $\mathrm{SF}_{2}$ was accompanied by significantly reduction in fruit setting percentage. The interaction effect between NPK fertigation rate and starter fertilizer showed that NPK fertigation rate of $125 \%+$ SF had the highest mean values of plant height at all growth stages and number of leaf and branches at 30 DAS. Application of $\mathrm{SF}_{1}$ or $\mathrm{SF}_{2}$ combined with $125 \%$ of recommended NPK resulted in the highest significant mean values for the fruit setting $\%$ and number fruits per plant, fruit yield and leaf's $P$ and $K$ contents.
\end{abstract}

Keywords: NPK fertigation rate, growth stages, minerals contents, fruit yield

\section{Introduction}

Cucumber (Cucumis sativus L. $2 \mathrm{n}=14$ ) is one of the most popular and widely grown vegetable crops in the world, and one of the oldest vegetables cultivated by early man (Eifediyi \& Remison, 2010), as considered the main greenhouse crop in Saudi Arabia. High temperatures in most around of Saudi Arabia during the year lead to increase the consumption of cucumber fruit throughout the year. Whereas, cucumber fruit is a moisturizer for the human body and reduce the body's need for water.

Fertilizer is a major part of the crop expenses for cucumber production, and it is critical for successful crop yields and high fruit quality. Fertilizer requirements of cucumber are quite high due to its high yielding potential per unit area and time. Accordingly, mineral nutrition with suitable levels of nitrogen $(\mathrm{N})$, phosphorus $(\mathrm{P})$ and potassium (K) had a key role for improving the growth and fruit yield of cucumber, as well as influencing the cucumber plant's ability to withstand negative effects from pests, water, temperature, and other stresses. N, along with $\mathrm{P}$ and $\mathrm{K}$, are classified as primary macronutrient, which are needed in relatively large quantities and are often deficient in crops not receiving fertilizer application (Marschner, 1986).

Use of drip irrigation in the vegetable production, under the greenhouse, causes a restriction of the plant root system spread and that concentrated only in the wetness root zone. For this reason it is requires to the frequent supplying of irrigation water and fertilizers (fertigation) for the root zone soil (rhizosphere), through critical periods of nutrient demand of crop (Mikkelsen, 1989; Kohzushka \& Romanets, 1994; Qasim et al., 2008). However, the excessive use of NPK fertilizers create pollution of agro-ecosystem through contamination the 
underground water with nitrate $\left(\mathrm{NO}_{3}\right)$ and increasing $\mathrm{NO}_{3}$ accumulation in food chain causing hazardous effects, as well as destroy micro-organisms and friendly insects, making the crop more disposed to diseases and reduced soil fertility (Fischer \& Richter, 1984; Mahdi et al., 2010). Moreover, most NPK fertilizers are a high solubility and the crop uses about $50 \%$ of the amount applied especially in the sandy soil and the rest lost by lixiviation, or goes into the atmosphere. Therefore, improve the agricultural practices of cucumber crop production under drip irrigation are of great economic interest. This may be achieved by applying for the new fertilization policies, by using the starter fertilizers (SF) rich in phosphorus mainly to accelerate root development with application of suitable NPK fertilizers rate through the irrigation system (fertigation).

Through a fertigation can be injected one or more fertilizers in a small amount with irrigation water and applied at various frequencies (daily, every other day, several times each week, or weekly to bi-monthly), depending mainly on crop type, fertigation program, soil type and on grower preference (Feleafel \& Mirdad, 2013). Fertigation has been found as one of the most successful ways of application the water and nutrient, particularly, $\mathrm{N}, \mathrm{K}$ and micronutrient. The right combination of water and nutrients in fertigation program is the key for high yield and quality of cucumber. Considerable amounts of investigations were devoted to determine the impacts of the NPK fertigation rates on the growth, fruit yield and quality of the cucumber and other vegetable crops such as (Miller et al., 1976; Abdel-Aziz, 1998; Feleafel \& Mirdad, 2013).

Starter fertilizers (SF) are the solutions rich in phosphorus (P) mainly, used by a small amount, applied near close to the seed or around the roots of transplants at/or just after transplanting (Stone, 2000). The purpose of application of SF is to supply the nutrients in the early stages of growth before the root system is sufficiently developed to reach banded fertilizer (Dufault \& Schulthesis, 1994). Furthermore, it contributes to overcome transplant shock and get young plants off to a good start (Stone, 1998, 2000) as well as to accelerate root development, hence increasing the plant's capacity to absorb more nutrients from the soil (Asian vegetable research and development center (AVRDC) reports (1999-2004). Jokela (1992) reported that high P concentration near the young root system may lead to increased $\mathrm{P}$ uptake and development of strong roots. Similarly, Stone $(1998,2000)$ found that injection of small quantities of P and N fertilizers, at sowing, lead to increase in the early growth of bulb onion, salad onion, leek and lettuce. Feleafel and Mirdad (2014) reported that tomato plants receiving starter fertilizer at rate $150-300-150 \mathrm{mg} / \mathrm{l}$ of $\mathrm{N}-\mathrm{P}_{2} \mathrm{O}_{5}-\mathrm{K}_{2} \mathrm{O}$ as drench achieved maximum root and shoot fresh weight and highest mean values of the number of flowers per cluster, leaf NK contents and fruit yield per plant.

In Saudi Arabia, most of the cucumber farmers do not use any soil or water analysis for planning their program of fertigation. They usually depend on their own experience. Moreover, fertilization recommendations, based on research conducted regionally or locally, showed their differences between the regions of the country. Therefore, it is important to recognize these regional differences when formulating the program of fertigation. Additionally, few studies reported the effect of SF and drip fertigation rate on the growth, fruit yields, and leaf mineral contents of cucumber.

This research is an attempt to form strong roots in the early growth stages by using starter fertilizers and thus increase the NPK fertigation use efficiency through planning strategic program for irrigation water and fertigation rates. The aim of this study was explore the effect of the starter fertilizers and NPK fertigation rates on the growth, fruit yield, and minerals contents of cucumber plants grown an under greenhouse.

\section{Materials and Methods}

Two greenhouse experiments by using drip irrigation system were conducted at Agricultural Researches Station, Hada-Alsham, King Abdulaziz University, Saudi Arabia, at the same time in the spring season of 2013. To investigate the effects of four fertigation rates; $50 \%, 75 \%, 100 \%$ and $125 \%$ of NPK recommended; $220,150,150$ $\mathrm{kg} \mathrm{N}, \mathrm{P}_{2} \mathrm{O}_{5}, \mathrm{~K}_{2} \mathrm{O}$ ha ${ }^{-1}$, respectively and three starter fertilizers (SF); $\mathrm{SF}_{0}$ (control), $\mathrm{SF}_{1}:$ 7-14-7 and $\mathrm{SF}_{2}: 7-28-7 \mathrm{~kg}$ $\mathrm{N}-\mathrm{P}_{2} \mathrm{O}_{5}-\mathrm{K}_{2} \mathrm{O}$ ha ${ }^{-1}$ as well as their interactions on the performance characters of cucumber plants, cv. Alrased 92 $\mathrm{F}_{1}$.

Preceding the initial of each experiment, some important physical and chemical properties of the two experimental sites soil up to $30 \mathrm{~cm}$ depth and chemical properties of irrigation water, which obtained from a local well, were estimated according to the published procedures by (Page et al., 1982) and the results are listed in Table 1. 
Table 1. Soil's physical and chemical properties of the two experimental sites and chemical properties of irrigation water

\begin{tabular}{|c|c|c|c|c|c|c|c|c|}
\hline \multirow{2}{*}{ Trials } & \multicolumn{4}{|c|}{ Physical properties } & \multicolumn{2}{|c|}{ Chemical properties } & \multirow{2}{*}{$\mathbf{N}(\%)$} & \multirow{2}{*}{$\mathbf{P}(\mathbf{p p m})$} \\
\hline & Clay $(\%)$ & Silt (\%) & Sand (\%) & Soil texture & pH & E.C $\left(d_{s ~ ~^{-1}}\right)$ & & \\
\hline First trial & 15.7 & 17.9 & 66.4 & Sandy loam & 8.2 & 3.38 & 0.18 & 31.8 \\
\hline Second trial & 16.6 & 18.2 & 65.2 & Sandy loam & 8.4 & 3.34 & 0.16 & 31.5 \\
\hline \multicolumn{9}{|c|}{ Chemical properties of irrigation water } \\
\hline$E C\left(\mathrm{dS} \mathrm{m}^{-1}\right)$ & $\mathrm{Na}\left(\operatorname{meq~} \mathrm{l}^{-1}\right)$ & $\operatorname{Mg}\left(\right.$ meq $\left.^{-1}\right)$ & $\mathrm{Ca}\left(\mathrm{meq} \mathrm{I}^{-1}\right)$ & HCO3 $\left(\right.$ meq $\left.\mathrm{I}^{-1}\right)$ & & $\mathrm{Cl}\left(\operatorname{meq~}^{-1}\right)$ & SO4 & $\left.\operatorname{meq} \mathrm{I}^{-1}\right)$ \\
\hline 2.41 & 0.42 & 0.35 & 5.44 & 0.65 & & 1.88 & & .73 \\
\hline
\end{tabular}

The experimental layout was split plots system in a Randomized Complete Blocks Design with three replications. Each replicate included 12 treatments, which were the combinations of four NPK fertigation rates and three starter fertilizer (SF). The NPK fertigation rates were, randomly, arranged in the main plots, while starter fertilizers were, randomly, distributed in the sub-plots. Each sub-plot consisted of two ridges; each ridge was $2.00 \mathrm{~m}$ length and $1.5 \mathrm{~m}$ width. The area of the smallest experimental unit is $6 \mathrm{~m}^{2}$. Seeds of the cucumber (cv. Alrased $92 F_{1}$, gynoecious; all female flowers), were sown on February 27, 2013, in two lines on each row. The row spacing was $50 \mathrm{~cm}$ between the seeds and $70 \mathrm{~cm}$ between the lines. Each sub-plot was contained 16 plants. The quantities of SF were dissolved in $2 \mathrm{~m}^{3} /$ ha water. Starter solution was used as a drench to the seedling root area, one week after seeding, at a rate 0.11 per plant. The control plants were treated with tap water.

The actual evapotranspiration of the cucumber crop (ETc), under greenhouse at Hada-Alsham area conditions, was calculated and adjusted at the beginning of each growth stage. It's calculated by multiplying reference evapotranspiration $\left(\mathrm{ET}_{0}\right)$ for different growth stages throughout the growing season (November, 2010 - March, 2011) by a crop coefficient $\left(\mathrm{K}_{\mathrm{C}}\right)$; $\mathrm{ETc}=\mathrm{ET}_{0} \times \mathrm{Kc}$, as indicated in Allen et al. (1998) and Razmi and Ghaemi (2011) (Table 2). The drip irrigation network consisted of lateral's GR of $16 \mathrm{~mm}$ in diameter, with emitters at 0.5 $\mathrm{m}$ distance, with allocating two laterals for each row. The emitters had a discharge rate $4 \mathrm{l} / \mathrm{h}$. Irrigation frequency was every alternate day, to maintain soil moisture above $50 \%$ soil moisture depletion, according to Qassim and Ashcroft (2002), which is the optimum level of cucumber plants.

Table 2. Length of the growth stages, crop coefficients $\left(\mathrm{K}_{\mathrm{c}}\right)$, reference evapotranspiration $\left(\mathrm{ET}_{0}\right)$ and water requirements of cucumber crop $\left(\mathrm{ET}_{\mathrm{c}}\right)$, under the greenhouse at Hada-Alsham region conditions, Saudi Arabia

\begin{tabular}{lccc}
\hline \multicolumn{1}{c}{ Growth stages } & Establishment & Vegetative & Flowering and fruiting \\
\hline Number of days per stage & 20 & 30 & 55 \\
Crop Coefficients $\left(\mathrm{K}_{\mathrm{C}}\right)$ & 0.41 & 0.70 & 0.93 \\
$\begin{array}{l}\text { Reference evapotranspiration }\left(\mathrm{ET}_{0}\right) \mathrm{mm} \\
\text { day-1 on the inside of the greenhouse }=73 \% \\
\text { from outside the greenhouse (Razmi and }\end{array}$ & 4.1 & 4.6 & 5.1 \\
$\begin{array}{l}\text { Ghaemi, 2011) } \\
\text { Water requirements of tomato crop (ET }) \\
\text { mm/day }\end{array}$ & 1.68 & 3.22 & 4.8 \\
$\begin{array}{l}\text { Total water requirements per growth stage } \\
(394.2 \text { mm) }\end{array}$ & 33.6 & 96.6 & 264 \\
\hline
\end{tabular}

The fertilizers that used in the experiments were NPK (20-20-20), urea (46\% N), phosphoric acid $\left(58 \% \mathrm{P}_{2} \mathrm{O}_{5}\right)$, potassium sulfate $\left(48 \% \mathrm{~K}_{2} \mathrm{O}\right)$. NPK fertilizers were injected directly into the irrigation water (fertigation) using a venture injector at two doses weekly starting in the $2^{\text {nd }}$ week after seeding up to the $14^{\text {th }}$ week. The schedule of the percentage of NPK fertigation and fertigation frequency during the varied growth stages of cucumber plants are shown in Table 3. The average temperature and relative air humidity inside the greenhouse were $24 \pm 2.7^{\circ} \mathrm{C}$ and $73 \pm 2 \%$ through tomato growth stages, respectively. Other recommended agricultural practices were followed as commonly used in the commercial production of cucumber. 
Table 3. Schedule of the percentage of NPK fertigation and fertigation frequency during the varied growth stages of cucumber plants

\begin{tabular}{cccccc}
\hline \multicolumn{2}{c}{ Treatments } & & \multicolumn{2}{c}{ Percentage and time of NPK addition } \\
\% NPK* & $\begin{array}{c}\text { Fertigation } \\
\text { frequency }\end{array}$ & Total doses No. & $\begin{array}{c}\text { Vegetative growth } \\
\text { stage 2-5 WAS** }\end{array}$ & $\begin{array}{c}\text { Flowering and fruiting } \\
\text { stages 6-14 WAS }\end{array}$ \\
\hline 50 & 2 doses weekly & 24 & $3 \% \times 8$ & $7 \% \times 16$ \\
75 & 2 doses weekly & 24 & $3 \% \times 8$ & $7 \% \times 16$ \\
100 & 2 doses weekly & 24 & $3 \% \times 8$ & $7 \% \times 16$ \\
125 & 2 doses weekly & 24 & $3 \% \times 8$ & $7 \% \times 16$ \\
\hline
\end{tabular}

* NPK of recommended $=220-150-150 \mathrm{Kg} / \mathrm{ha}$;

$* * \mathrm{WAS}=$ Weeks after sowing.

\subsection{Data Recorded}

Vegetative growth characters: Five randomly chosen plants, in each sub-plot, were tagged and the plant height and number of leaves and branches per plant characters were recorded at 30,50 and 70 days after sowing seeds (DAS).

Leaf mineral contents: Chemical analysis of cucumber leaves were carried out to determine mineral contents $(\mathrm{N}, \mathrm{P}$, and $\mathrm{K}$ ) as percentage were determined as described in Cottenie (1980).

Fruit yield and fruits setting: Cucumber fruits at a marketable stage were harvested twice weekly starting at 40 DAS and continued until the 105 DAS. The fruits yield per plant, mean weight of fruit, fruits number per plant and fruits setting percentage were recorded.

\subsection{Statistical Analysis}

All obtained data of the present study was, statistically, analyzed according to the design used by the MSTATC computer software program (Bricker 1991). The comparisons among means of the different treatments were carried out by using the revised LSD test at $\mathrm{P}>0.05$.

\section{Results}

\subsection{Vegetative Growth Characters}

\subsubsection{Plant Height}

Application of NPK fertigation rates up to $125 \%$ of recommended $\left(220-150-150 \mathrm{Kg} \mathrm{N}-\mathrm{P}_{2} \mathrm{O}_{5}-\mathrm{K}_{2} \mathrm{O} / \mathrm{ha}\right)$, to the growing cucumber plants, resulted in significant increases in the plant height at all growth stages $(30,50$ and 70 DAS), in both experiments (Table 4). 
Table 4. Effect of NPK fertigation rates and starter fertilizer on the plant height $(\mathrm{cm})$ of cucumber plant, at 30, 50, 70 DAS

\begin{tabular}{|c|c|c|c|c|c|c|c|}
\hline \multirow{2}{*}{\multicolumn{2}{|c|}{ Treatments ${ }^{*}$}} & \multicolumn{6}{|c|}{ Plant height (cm) } \\
\hline & & \multicolumn{2}{|c|}{30 DAS $^{* * *}$} & \multicolumn{2}{|c|}{50 DAS } & \multicolumn{2}{|c|}{70 DAS } \\
\hline NPK \% & Starter fertilizer & $1^{\text {st }}$ Trial & $2^{\text {nd }}$ Trial & $1^{\text {st }}$ Trial & $2^{\text {nd }}$ Trial & $1^{\text {st }}$ Trial & $2^{\text {nd }}$ Trial \\
\hline 50 & & $90.5 \mathrm{D}^{* *}$ & $84.8 \mathrm{D}$ & $185.0 \mathrm{C}$ & $194.5 \mathrm{D}$ & $241.83 \mathrm{D}$ & $262.0 \mathrm{~B}$ \\
\hline 75 & & $109.4 \mathrm{C}$ & $105.0 \mathrm{C}$ & 193.0B & $198.9 \mathrm{C}$ & $252.30 \mathrm{~B}$ & $256.3 \mathrm{C}$ \\
\hline 100 & & $120.5 \mathrm{~B}$ & 129.1B & $197.2 \mathrm{~A}$ & 202.4B & $250.53 \mathrm{C}$ & $251.6 \mathrm{D}$ \\
\hline \multirow[t]{5}{*}{125} & & $126.9 \mathrm{~A}$ & $135.4 \mathrm{~A}$ & $198.3 \mathrm{~A}$ & $205.6 \mathrm{~A}$ & $254.93 \mathrm{~A}$ & $266.0 \mathrm{~A}$ \\
\hline & $\mathrm{SF}_{0}$ & $104.1 \mathrm{C}$ & $109.3 \mathrm{C}$ & $187.8 \mathrm{C}$ & $192.5 \mathrm{~B}$ & $241.54 \mathrm{C}$ & $259.1 \mathrm{C}$ \\
\hline & $\mathrm{SF}_{1}$ & $118.7 \mathrm{~A}$ & $120.1 \mathrm{~A}$ & 194.5B & $204.2 \mathrm{~A}$ & $255.83 \mathrm{~A}$ & $262.0 \mathrm{~A}$ \\
\hline & $\mathrm{SF}_{2}$ & $112.6 \mathrm{~B}$ & $111.2 \mathrm{~B}$ & $198.0 \mathrm{~A}$ & $204.3 \mathrm{~A}$ & $252.33 \mathrm{~B}$ & $255.8 \mathrm{~B}$ \\
\hline & $\mathrm{SF}_{0}$ & $77.5 \mathrm{~d}$ & $67.5 f$ & $178.6 \mathrm{c}$ & $184.4 \mathrm{ab}$ & $221.0 \mathrm{~b}$ & 275.9ab \\
\hline \multirow[t]{3}{*}{50} & $\mathrm{SF}_{1}$ & $98.5 \mathrm{bc}$ & $95.1 \mathrm{def}$ & $184.9 \mathrm{bc}$ & $198.9 \mathrm{ab}$ & $253.3 \mathrm{a}$ & $260.6 a b c$ \\
\hline & $\mathrm{SF}_{2}$ & $95.4 \mathrm{~cd}$ & $91.7 \mathrm{ef}$ & 191.6abc & $200.0 \mathrm{ab}$ & $251.2 \mathrm{a}$ & $249.7 \mathrm{bc}$ \\
\hline & $\mathrm{SF}_{0}$ & $99.9 \mathrm{bc}$ & $91.6 \mathrm{ef}$ & $198.6 \mathrm{ab}$ & $172.3 b$ & $245.7 \mathrm{ab}$ & $251.4 \mathrm{bc}$ \\
\hline \multirow[t]{3}{*}{75} & $\mathrm{SF}_{1}$ & $113.0 \mathrm{abc}$ & $111.3 \mathrm{cde}$ & $192.2 \mathrm{abc}$ & $216.1 \mathrm{a}$ & $261.7 \mathrm{a}$ & $254.1 \mathrm{bc}$ \\
\hline & $\mathrm{SF}_{2}$ & $115.3 \mathrm{ab}$ & $112.0 \mathrm{cde}$ & $188.1 \mathrm{bc}$ & $208.3 \mathrm{a}$ & $249.5 \mathrm{ab}$ & 263.3abc \\
\hline & $\mathrm{SF}_{0}$ & $111.5 \mathrm{abc}$ & 131.3abc & 198.6ab & 205.5ab & $254.5 \mathrm{a}$ & $246.7 \mathrm{c}$ \\
\hline \multirow[t]{3}{*}{100} & $\mathrm{SF}_{1}$ & $129.8 \mathrm{a}$ & $132.7 \mathrm{abc}$ & $192.2 \mathrm{abc}$ & $191.8 \mathrm{ab}$ & $250.1 \mathrm{ab}$ & $248.9 \mathrm{bc}$ \\
\hline & $\mathrm{SF}_{2}$ & $120.1 \mathrm{a}$ & 123.1a-d & $188.1 \mathrm{bc}$ & $209.9 \mathrm{a}$ & $247.0 \mathrm{ab}$ & $259.1 \mathrm{abc}$ \\
\hline & $\mathrm{SF}_{0}$ & $127.7 \mathrm{a}$ & $147.0 \mathrm{a}$ & $177.6 \mathrm{c}$ & $207.8 \mathrm{a}$ & $245.0 \mathrm{ab}$ & $262.7 \mathrm{abc}$ \\
\hline \multirow[t]{2}{*}{125} & $\mathrm{SF}_{1}$ & $133.6 \mathrm{a}$ & $141.7 \mathrm{ab}$ & $209.6 \mathrm{a}$ & $210.0 \mathrm{a}$ & $258.2 \mathrm{a}$ & $284.5 \mathrm{a}$ \\
\hline & $\mathrm{SF}_{2}$ & $119.6 \mathrm{a}$ & $117.7 \mathrm{~b}-\mathrm{e}$ & $207.8 \mathrm{a}$ & $198.9 \mathrm{ab}$ & $261.7 \mathrm{a}$ & $251.1 \mathrm{bc}$ \\
\hline
\end{tabular}

* NPK treatments; 50, 75,100 and 125\% of recommended; 220, 150, 150kg N, $\mathrm{P}_{2} \mathrm{O}_{5}, \mathrm{~K}_{2} \mathrm{O}$ /ha, respectively, starter fertilizer (SF); $\mathrm{SF}_{0}$ (control), $\mathrm{SF}_{1}:$ 7-14-7 and $\mathrm{SF}_{2}: 7-28-7 \mathrm{~kg} \mathrm{~N}-\mathrm{P}_{2} \mathrm{O}_{5}-\mathrm{K}_{2} \mathrm{O} /$ ha.

${ }^{* *}$ Values having the same alphabetical letter in common, within a particular group of means in each character, do not significantly differ, using the revised LSD test at $\mathrm{P}<0.05$.

${ }^{* * *}$ DAS: days after sowing.

The results in Table 4 indicated clearly that plant height of cucumber plants significantly differed, at all growth stages with application of NPK starter fertilizer. At 30 and 70 DAS, cucumber plants receiving $\mathrm{SF}_{1}(7-14-7 \mathrm{~kg}$ $\mathrm{N}-\mathrm{P}_{2} \mathrm{O}_{5}-\mathrm{K}_{2} \mathrm{O} /$ ha) had the tallest plant height followed by plants receiving $\mathrm{SF}_{2}$ and plants in control treatment. While, at 50 DAS, cucumber plant height significantly, increased in the cucumber plants receiving $\mathrm{SF}_{2}$ compared with control treatment, in two experiments.

The interaction effects of NPK fertigation rates and starter fertilizers on the cucumber plant height were significant (Table 4) at all growth stages but by different trends. At $30 \mathrm{DAS}$, the data indicated that cucumber plant that received any SF rates $+100 \%$ of NPK recommended (220-150-150 Kg N-P $\mathrm{P}_{2} \mathrm{O}_{5}-\mathrm{K}_{2} \mathrm{O} / \mathrm{ha}$ ), generally, caused an increase in the plant height. At 50 DAS, the comparisons among the means of the various combined treatments, clearly, showed that the soil application of $\mathrm{SF}_{1}$ with NPK at rate $125 \%$ of recommended seemed to be the best treatment combination as gave the peak values for the cucumber plant height. The comparisons at 70 DAS illustrated that the cucumber plant height reflected significant increase with $75 \%$ of NPK recommended + $\mathrm{SF}_{1}$ (7-14-7 kg N-P $\mathrm{O}_{5}-\mathrm{K}_{2} \mathrm{O} / \mathrm{ha}$ ). Such an interaction effect was not noticed in the second experiment. While the highest value of plant height achieved with $\mathrm{SF}_{1}$ or $\mathrm{SF}_{2}+\mathrm{NPK}$ at $125 \%$ of recommended in the first and second experiment, orderly. 


\subsubsection{Number of Leaves per Plant}

Increasing the NPK fertigation rate up to $125 \%$ of recommended significantly increased the number of leaves per plant of cucumber at 30,50, and 70 DAS, in both experiments (Table 5).

Table 5. Effect of NPK fertigation rates and starter fertilizer on the leaves number of cucumber plant, at 30, 50, 70 DAS

\begin{tabular}{|c|c|c|c|c|c|c|c|}
\hline \multirow{2}{*}{\multicolumn{2}{|c|}{ Treatments" }} & \multicolumn{6}{|c|}{ Number of leaves } \\
\hline & & \multicolumn{2}{|c|}{30 DAS $^{* * *}$} & \multicolumn{2}{|c|}{50 DAS } & \multicolumn{2}{|c|}{70 DAS } \\
\hline NPK \% & Starter fertilizer & $1^{\text {st }}$ Trial & $2^{\text {nd }}$ Trial & $1^{\text {st }}$ Trial & $2^{\text {nd }}$ Trial & $1^{\text {st }}$ Trial & $2^{\text {nd }}$ Trial \\
\hline 50 & & $14.5 \mathrm{~B}^{* *}$ & $13.0 \mathrm{C}$ & $22.5 \mathrm{C}$ & $22.7 \mathrm{D}$ & $31.5 \mathrm{C}$ & $31.1 \mathrm{C}$ \\
\hline 75 & & $16.8 \mathrm{AB}$ & $15.1 \mathrm{~B}$ & $27.9 \mathrm{~B}$ & $28.1 \mathrm{C}$ & $32.4 \mathrm{~B}$ & $33.0 \mathrm{~B}$ \\
\hline 100 & & $17.7 \mathrm{~A}$ & $17.9 \mathrm{~A}$ & $29.6 \mathrm{~A}$ & $29.8 \mathrm{~B}$ & $33.5 \mathrm{~A}$ & $33.5 \mathrm{~B}$ \\
\hline \multirow[t]{5}{*}{125} & & $18.3 \mathrm{~A}$ & $18.0 \mathrm{~A}$ & $30.4 \mathrm{~A}$ & $31.6 \mathrm{~A}$ & $33.5 \mathrm{~A}$ & $35.5 \mathrm{~A}$ \\
\hline & $\mathrm{SF}_{0}$ & $15.6 \mathrm{C}$ & $15.0 \mathrm{C}$ & $26.2 \mathrm{~B}$ & $26.5 \mathrm{~B}$ & $32.8 \mathrm{~A}$ & $33.4 \mathrm{~A}$ \\
\hline & $\mathrm{SF}_{1}$ & $17.8 \mathrm{~A}$ & $16.8 \mathrm{~A}$ & $28.3 \mathrm{~A}$ & $28.6 \mathrm{~A}$ & $32.9 \mathrm{~A}$ & $33.0 \mathrm{~A}$ \\
\hline & $\mathrm{SF}_{2}$ & $17.0 \mathrm{~B}$ & $16.2 \mathrm{~B}$ & $28.3 \mathrm{~A}$ & $29.0 \mathrm{~A}$ & $32.8 \mathrm{~A}$ & $33.3 \mathrm{~A}$ \\
\hline & $\mathrm{SF}_{0}$ & $11.6 \mathrm{~d}$ & $10.1 \mathrm{e}$ & $19.2 \mathrm{~g}$ & $18.6 \mathrm{~g}$ & $32.0 \mathrm{a}$ & $30.8 \mathrm{c}$ \\
\hline \multirow[t]{3}{*}{50} & $\mathrm{SF}_{1}$ & $15.9 \mathrm{c}$ & $14.7 \mathrm{~cd}$ & $23.7 \mathrm{f}$ & $24.3 \mathrm{f}$ & $31.0 \mathrm{a}$ & $30.9 \mathrm{c}$ \\
\hline & $\mathrm{SF}_{2}$ & $16.0 \mathrm{c}$ & $14.3 \mathrm{~d}$ & $24.5 \mathrm{ef}$ & $25.2 \mathrm{ef}$ & $31.3 \mathrm{a}$ & $31.8 \mathrm{bc}$ \\
\hline & $\mathrm{SF}_{0}$ & 16.4abc & $14.2 \mathrm{~d}$ & $26.3 \mathrm{de}$ & $26.7 \mathrm{def}$ & $33.2 \mathrm{a}$ & $34.3 \mathrm{abc}$ \\
\hline \multirow[t]{3}{*}{75} & $\mathrm{SF}_{1}$ & $17.2 \mathrm{bc}$ & $15.5 \mathrm{bcd}$ & $28.8 \mathrm{c}$ & $28.2 \mathrm{dce}$ & $31.8 \mathrm{a}$ & $31.5 \mathrm{bc}$ \\
\hline & $\mathrm{SF}_{2}$ & $16.8 \mathrm{c}$ & $15.8 \mathrm{bcd}$ & $28.6 \mathrm{~cd}$ & $29.5 \mathrm{bcd}$ & $32.2 \mathrm{a}$ & $33.0 \mathrm{abc}$ \\
\hline & $\mathrm{SF}_{0}$ & $16.4 \mathrm{ab}$ & $17.3 \mathrm{a}-\mathrm{d}$ & $29.3 b c$ & $29.1 \mathrm{bcd}$ & $33.5 \mathrm{a}$ & $32.7 \mathrm{abc}$ \\
\hline \multirow[t]{3}{*}{100} & $\mathrm{SF}_{1}$ & 18.9abc & 17.9abc & $31.3 \mathrm{ab}$ & $31.8 \mathrm{ab}$ & $33.4 \mathrm{a}$ & 34.1abc \\
\hline & $\mathrm{SF}_{2}$ & 17.8abc & $18.6 \mathrm{ab}$ & $28.2 \mathrm{~cd}$ & $28.7 \mathrm{bcd}$ & $33.7 \mathrm{a}$ & 33.9abc \\
\hline & $\mathrm{SF}_{0}$ & 18.0abc & $18.6 \mathrm{ab}$ & $30.0 \mathrm{abc}$ & $31.8 \mathrm{ab}$ & $32.6 \mathrm{a}$ & $36.0 \mathrm{a}$ \\
\hline \multirow[t]{2}{*}{125} & $\mathrm{SF}_{1}$ & $19.3 \mathrm{a}$ & $19.3 \mathrm{a}$ & $29.2 \mathrm{bc}$ & $30.2 \mathrm{abc}$ & $35.2 \mathrm{a}$ & $35.7 \mathrm{a}$ \\
\hline & $\mathrm{SF}_{2}$ & 17.7abc & $16.1 \mathrm{a}-\mathrm{d}$ & $32.0 \mathrm{a}$ & $33.0 \mathrm{a}$ & $33.8 \mathrm{a}$ & $34.9 \mathrm{ab}$ \\
\hline
\end{tabular}

* NPK treatments; 50, 75,100 and $125 \%$ of recommended; $220,150,150 \mathrm{~kg} \mathrm{~N}, \mathrm{P}_{2} \mathrm{O}_{5}, \mathrm{~K}_{2} \mathrm{O} /$ ha, respectively, starter fertilizer (SF); $\mathrm{SF}_{0}$ (control), $\mathrm{SF}_{1}$ : 7-14-7 and $\mathrm{SF}_{2}: 7-28-7 \mathrm{~kg} \mathrm{~N}-\mathrm{P}_{2} \mathrm{O}_{5}-\mathrm{K}_{2} \mathrm{O} /$ ha.

${ }^{* *}$ Values having the same alphabetical letter in common, within a particular group of means in each character, do not significantly differ, using the revised LSD test at $\mathrm{P}<0.05$.

${ }^{* * *}$ DAS: days after sowing.

Concerning the effect of starter fertilizer on the number of leaves per plant of cucumber, at 30 and 50 DAS (Table 5), the results appeared that the cucumber plants receiving any SF rates achieved an increase in the number of leaves, in two experiments. While, at 70 DAS, the results revealed that the number of leaves per plant was did not show any response to the use of SF rates, in two experiments.

The comparisons among the various treatment combinations means of the number of leaves per plant did not suggest any constant interaction effects between the NPK fertigation rates and NPK starter fertilizers on this character at all growth stages. At 30 and 50 DAS (Table 5), the data showed that cucumber plants receiving SF rates appeared an increase in the number of leaves per plant under the low rates of NPK fertigation ( 50 and $75 \%$ of recommended), this not so at 70 DAS .

\subsubsection{Number of Branches per Plant}

Number of branches per plant of cucumber revealed significant increases with each increase in applied for NPK 
fertigation rates up to $125 \%$ of recommended, in both experiments, especially in early growth stage at 30 DAS stage only (Table 6). However, the results showed that number of branches per plant character was noticed to be insignificantly affected by the different NPK fertigation rates, in the later growth stages at 50 and 70 DAS, in both experiments.

Table 6. Effect of NPK fertigation rates and starter fertilizer on the branches number of cucumber plant, at 30, 50, 70 DAS

\begin{tabular}{|c|c|c|c|c|c|c|c|}
\hline \multirow{2}{*}{\multicolumn{2}{|c|}{ Treatments $^{*}$}} & \multicolumn{6}{|c|}{ Branches number } \\
\hline & & \multicolumn{2}{|c|}{$30 \mathrm{DAS}^{* * *}$} & \multicolumn{2}{|c|}{50 DAS } & \multicolumn{2}{|c|}{70 DAS } \\
\hline NPK \% & Starter fertilizer & $1^{\text {st }}$ Trial & $2^{\text {nd }}$ Trial & $1^{\text {st }}$ Trial & $2^{\text {nd }}$ Trial & $1^{\text {st }}$ Trial & $2^{\text {nd }}$ Trial \\
\hline 50 & & $8.3 \mathrm{D}^{* *}$ & $6.9 \mathrm{C}$ & $16.8 \mathrm{~A}$ & $16.8 \mathrm{~A}$ & $21.4 \mathrm{~A}$ & $21.2 \mathrm{~A}$ \\
\hline 75 & & $9.2 \mathrm{C}$ & $8.2 \mathrm{~B}$ & $17.4 \mathrm{~A}$ & $17.0 \mathrm{~A}$ & $21.1 \mathrm{~A}$ & $21.4 \mathrm{~A}$ \\
\hline 100 & & $10.3 \mathrm{~B}$ & $9.7 \mathrm{~B}$ & $17.4 \mathrm{~A}$ & $17.4 \mathrm{~A}$ & $21.3 \mathrm{~A}$ & $21.7 \mathrm{~A}$ \\
\hline \multirow[t]{5}{*}{125} & & $12.3 \mathrm{~A}$ & $12.6 \mathrm{~A}$ & $17.6 \mathrm{~A}$ & $18.0 \mathrm{~A}$ & $21.4 \mathrm{~A}$ & $21.7 \mathrm{~A}$ \\
\hline & $\mathrm{SF}_{0}$ & $9.2 \mathrm{~B}$ & $8.9 \mathrm{~B}$ & $17.6 \mathrm{~A}$ & $17.9 \mathrm{~A}$ & $21.2 \mathrm{~A}$ & $21.4 \mathrm{~A}$ \\
\hline & $\mathrm{SF}_{1}$ & $10.4 \mathrm{~A}$ & $9.1 \mathrm{~A}$ & $17.2 \mathrm{~A}$ & $17.1 \mathrm{~A}$ & $21.3 \mathrm{~A}$ & $21.4 \mathrm{~A}$ \\
\hline & $\mathrm{SF}_{2}$ & $10.6 \mathrm{~A}$ & $10.0 \mathrm{~A}$ & $16.9 \mathrm{~A}$ & $16.9 \mathrm{~A}$ & $21.3 \mathrm{~A}$ & $21.7 \mathrm{~A}$ \\
\hline & $\mathrm{SF}_{0}$ & $7.0 \mathrm{f}$ & $5.3 \mathrm{e}$ & $17.3 \mathrm{abc}$ & $17.1 \mathrm{~b}$ & $21.2 \mathrm{a}$ & $21.0 \mathrm{ab}$ \\
\hline \multirow[t]{3}{*}{50} & $\mathrm{SF}_{1}$ & 9.0def & 7.6de & $16.6 \mathrm{~d}$ & $16.6 \mathrm{~b}$ & $21.7 \mathrm{a}$ & $20.8 b$ \\
\hline & $\mathrm{SF}_{2}$ & $8.8 \mathrm{ef}$ & $7.8 \mathrm{de}$ & $16.5 \mathrm{~d}$ & $16.7 \mathrm{~b}$ & $21.3 \mathrm{a}$ & $21.8 \mathrm{a}$ \\
\hline & $\mathrm{SF}_{0}$ & $8.8 \mathrm{ef}$ & $7.8 \mathrm{de}$ & $16.8 \mathrm{~cd}$ & $16.8 \mathrm{~b}$ & $21.2 \mathrm{a}$ & $21.1 \mathrm{ab}$ \\
\hline \multirow[t]{3}{*}{75} & $\mathrm{SF}_{1}$ & $9.5 \mathrm{cde}$ & 8.0de & $17.0 \mathrm{abc}$ & $17.3 b$ & $21.8 \mathrm{a}$ & $21.3 \mathrm{ab}$ \\
\hline & $\mathrm{SF}_{2}$ & $9.6 \mathrm{cde}$ & $8.8 \mathrm{~cd}$ & $17.6 \mathrm{abc}$ & $17.1 \mathrm{~b}$ & $21.3 \mathrm{a}$ & $21.9 \mathrm{a}$ \\
\hline & $\mathrm{SF}_{0}$ & $9.5 \mathrm{cde}$ & $10.2 \mathrm{bcd}$ & $18.0 \mathrm{ab}$ & $18.1 \mathrm{ab}$ & $21.3 \mathrm{a}$ & $21.8 \mathrm{a}$ \\
\hline \multirow[t]{3}{*}{100} & $\mathrm{SF}_{1}$ & $10.9 \mathrm{bcd}$ & $9.4 \mathrm{bcd}$ & $17.2 \mathrm{abc}$ & $17.2 \mathrm{~b}$ & $21.3 \mathrm{a}$ & $21.7 \mathrm{a}$ \\
\hline & $\mathrm{SF}_{2}$ & $10.5 \mathrm{bcde}$ & $9.5 \mathrm{bcd}$ & $16.9 \mathrm{bcd}$ & $16.8 \mathrm{~b}$ & $21.3 \mathrm{a}$ & $21.6 \mathrm{a}$ \\
\hline & $\mathrm{SF}_{0}$ & 11.4abc & $12.2 \mathrm{ab}$ & $18.2 \mathrm{a}$ & $19.7 \mathrm{a}$ & $21.4 \mathrm{a}$ & $21.7 \mathrm{a}$ \\
\hline \multirow[t]{2}{*}{125} & $\mathrm{SF}_{1}$ & $12.1 \mathrm{ab}$ & $11.6 a b c$ & $17.8 \mathrm{abc}$ & $17.6 \mathrm{~b}$ & $21.3 \mathrm{a}$ & $22.0 \mathrm{a}$ \\
\hline & $\mathrm{SF}_{2}$ & $13.5 \mathrm{a}$ & $14.0 \mathrm{a}$ & $16.9 \mathrm{bcd}$ & $16.9 \mathrm{~b}$ & $21.5 \mathrm{a}$ & $21.5 \mathrm{a}$ \\
\hline
\end{tabular}

* NPK treatments; 50, 75,100 and 125\% of recommended; 220, 150, 150kg N, $\mathrm{P}_{2} \mathrm{O}_{5}, \mathrm{~K}_{2} \mathrm{O} /$ ha, respectively, starter fertilizer (SF); $\mathrm{SF}_{0}$ (control), $\mathrm{SF}_{1}$ : 7-14-7 and $\mathrm{SF}_{2}$ : 7-28-7 $\mathrm{kg} \mathrm{N}-\mathrm{P}_{2} \mathrm{O}_{5}-\mathrm{K}_{2} \mathrm{O} /$ ha.

${ }^{* *}$ Values having the same alphabetical letter in common, within a particular group of means in each character, do not significantly differ, using the revised LSD test at $\mathrm{P}<0.05$.

${ }^{* * *}$ DAS: days after sowing.

Data in Table 6, at 30 DAS growth stage, indicated that starter fertilizer caused significant increases in number of branches per plant, compared with control treatment. On the other hand, at other two growth stages (50 and 70 DAS) the results did not show significant differences of SF rates in their effects on the number of branches per plant.

At early growth stage (30 DAS) the highest values of the number of branches per plant achieved with the treatment combination of $\mathrm{SF}_{2}\left(7-28-7 \mathrm{Kg} \mathrm{N}-\mathrm{P}_{2} \mathrm{O}_{5}-\mathrm{K}_{2} \mathrm{O}\right)+125 \%$ of NPK recommended, in both experiments. However, at other growth stages (50 and 70 DAS) the results did not show clear trend of the treatment combinations of NPK fertigation rates and SF rates in their effects on the number of branches per plant of cucumber. 


\subsection{Leaf's Minerals Content}

NPK fertigation rates seemed to have clear effect on leaf's minerals ( $\mathrm{N}, \mathrm{P}$ and $\mathrm{K})$ contents as noticed from the comparisons listed in Table 7. The results indicated that the applying NPK fertigation up to $125 \%$ of recommended caused a significant increase in leaf minerals $(\mathrm{N}, \mathrm{P}$ and $\mathrm{K})$ contents of cucumber plant.

Table 7. Effect of NPK fertigation rates and starter fertilizer on the cucumber leaf's contents of N, P, and K (\%)

\begin{tabular}{|c|c|c|c|c|c|c|c|}
\hline \multirow{2}{*}{\multicolumn{2}{|c|}{ Treatments ${ }^{*}$}} & \multicolumn{6}{|c|}{ Leaves mineral contents } \\
\hline & & \multicolumn{2}{|c|}{$\mathbf{N}(\%)$} & \multicolumn{2}{|c|}{$\mathbf{P}(\%)$} & \multicolumn{2}{|c|}{$\mathrm{K}(\%)$} \\
\hline NPK \% & Starter fertilizer & $1^{\text {st }}$ Trial & $2^{\text {nd }}$ Trial & $1^{\text {st }}$ Trial & $2^{\text {nd }}$ Trial & $1^{\text {st }}$ Trial & $2^{\text {nd }}$ Trial \\
\hline 50 & & $1.918 \mathrm{C}^{* *}$ & $1.730 \mathrm{C}$ & $0.087 \mathrm{~B}$ & $0.080 \mathrm{C}$ & $1.455 \mathrm{~B}$ & $1.219 \mathrm{D}$ \\
\hline 75 & & $1.919 \mathrm{C}$ & $1.980 \mathrm{~B}$ & $0.089 \mathrm{~B}$ & $0.087 \mathrm{~B}$ & $1.538 \mathrm{~B}$ & $1.294 \mathrm{C}$ \\
\hline 100 & & $2.006 \mathrm{~B}$ & 1.990B & $0.093 \mathrm{~B}$ & $0.089 \mathrm{~B}$ & $1.551 \mathrm{~B}$ & $1.379 \mathrm{~B}$ \\
\hline \multirow[t]{5}{*}{125} & & $2.111 \mathrm{~A}$ & $2.019 \mathrm{~A}$ & $0.104 \mathrm{~A}$ & $0.109 \mathrm{~A}$ & $1.614 \mathrm{~A}$ & $1.484 \mathrm{~A}$ \\
\hline & $\mathrm{SF}_{0}$ & $1.980 \mathrm{~A}$ & $2.056 \mathrm{~A}$ & $0.087 \mathrm{~A}$ & $0.083 \mathrm{~A}$ & $1.541 \mathrm{~A}$ & $1.369 \mathrm{~B}$ \\
\hline & $\mathrm{SF}_{1}$ & $1.981 \mathrm{~A}$ & $1.800 \mathrm{~A}$ & $0.094 \mathrm{~A}$ & $0.088 \mathrm{~A}$ & $1.482 \mathrm{~A}$ & $1.180 \mathrm{C}$ \\
\hline & $\mathrm{SF}_{2}$ & $2.004 \mathrm{~A}$ & $1.933 \mathrm{~A}$ & $0.099 \mathrm{~A}$ & $0.102 \mathrm{~A}$ & $1.596 \mathrm{~A}$ & $1.483 \mathrm{~A}$ \\
\hline & $\mathrm{SF}_{0}$ & $1.937 \mathrm{bcd}$ & $1.697 \mathrm{bcd}$ & $0.083 b$ & $0.083 b$ & $1.445 \mathrm{bc}$ & $1.240 \mathrm{cde}$ \\
\hline \multirow[t]{3}{*}{50} & $\mathrm{SF}_{1}$ & $1.683 \mathrm{~d}$ & $1.447 \mathrm{~d}$ & $0.093 \mathrm{ab}$ & $0.080 \mathrm{~b}$ & $1.380 \mathrm{bc}$ & $0.960 \mathrm{e}$ \\
\hline & $\mathrm{SF}_{2}$ & $2.135 \mathrm{abc}$ & $2.047 \mathrm{ad}$ & $0.083 b$ & $0.077 \mathrm{~b}$ & $1.540 \mathrm{bc}$ & $1.457 \mathrm{bc}$ \\
\hline & $\mathrm{SF}_{0}$ & $1.927 \mathrm{bcd}$ & $2.263 \mathrm{a}$ & $0.088 \mathrm{ab}$ & $0.093 b$ & $1.090 \mathrm{~d}$ & $1.550 \mathrm{~b}$ \\
\hline \multirow[t]{3}{*}{75} & $\mathrm{SF}_{1}$ & $1.843 \mathrm{~cd}$ & $1.820 \mathrm{bc}$ & $0.083 b$ & $0.073 b$ & $1.552 \mathrm{bc}$ & $1.110 \mathrm{de}$ \\
\hline & $\mathrm{SF}_{2}$ & $1.988 \mathrm{bcd}$ & $1.857 \mathrm{bc}$ & $0.095 \mathrm{ab}$ & $0.093 \mathrm{~b}$ & $1.973 \mathrm{a}$ & $1.223 \mathrm{cde}$ \\
\hline & $\mathrm{SF}_{0}$ & $1.943 \mathrm{bcd}$ & 2.033ad & $0.090 \mathrm{ab}$ & $0.083 b$ & $1.910 \mathrm{a}$ & $1.527 b c$ \\
\hline \multirow[t]{3}{*}{100} & $\mathrm{SF}_{1}$ & $2.343 \mathrm{a}$ & $2.287 \mathrm{a}$ & $0.097 \mathrm{ab}$ & $0.103 b$ & $1.268 \mathrm{~cd}$ & $1.330 \mathrm{bcd}$ \\
\hline & $\mathrm{SF}_{2}$ & $1.690 \mathrm{~d}$ & $1.650 \mathrm{~cd}$ & $0.093 \mathrm{ab}$ & $0.080 \mathrm{~b}$ & $1.475 \mathrm{bc}$ & $1.280 \mathrm{bcd}$ \\
\hline & $\mathrm{SF}_{0}$ & $2.115 \mathrm{bcd}$ & $2.230 \mathrm{a}$ & $0.085 \mathrm{ab}$ & $0.073 b$ & $1.718 \mathrm{ab}$ & $1.160 \mathrm{cde}$ \\
\hline \multirow[t]{2}{*}{125} & $\mathrm{SF}_{1}$ & $2.013 \mathrm{bcd}$ & $1.647 \mathrm{~cd}$ & $0.103 \mathrm{ab}$ & $0.097 \mathrm{~b}$ & $1.727 \mathrm{ab}$ & $1.320 \mathrm{bcd}$ \\
\hline & $\mathrm{SF}_{2}$ & $2.203 \mathrm{ab}$ & $2.180 \mathrm{a}$ & $0.123 \mathrm{a}$ & $0.157 \mathrm{a}$ & $1.397 \mathrm{bc}$ & $1.973 \mathrm{a}$ \\
\hline
\end{tabular}

* NPK treatments; 50, 75,100 and $125 \%$ of recommended; 220, 150, 150kg N, $\mathrm{P}_{2} \mathrm{O}_{5}, \mathrm{~K}_{2} \mathrm{O} /$ ha, respectively, starter fertilizer (SF); $\mathrm{SF}_{0}$ (control), $\mathrm{SF}_{1}:$ 7-14-7 and $\mathrm{SF}_{2}: 7-28-7 \mathrm{~kg} \mathrm{~N}-\mathrm{P}_{2} \mathrm{O}_{5}-\mathrm{K}_{2} \mathrm{O} /$ ha.

${ }^{* *}$ Values having the same alphabetical letter in common, within a particular group of means in each character, do not significantly differ, using the revised LSD test at $\mathrm{P}<0.05$.

Cucumber plants receiving the soil application of starter fertilizers recorded insignificant effect on the leaf minerals ( $\mathrm{N}, \mathrm{P}$ and $\mathrm{K}$ ) contents of cucumber plant, in both experiments (Table 7). The only exception was noticed, in the second experiment, where the leaf's $\mathrm{K}$ content significantly increased with application of $\mathrm{SF}_{2}: 7-28-7 \mathrm{~N}-\mathrm{P}_{2} \mathrm{O}_{5}-\mathrm{K}_{2} \mathrm{O} / \mathrm{ha}$.

Data in Table (7) illustrated that the highest leaf's $\mathrm{N}$ content was achieved with soil application of $\mathrm{SF}_{1}(7-14-7$ $\left.\mathrm{N}-\mathrm{P}_{2} \mathrm{O}_{5}-\mathrm{K}_{2} \mathrm{O} / \mathrm{ha}\right)+100 \%$ of NPK, in the two experiments. Moreover, the results showed that there were no significant differences among the varying starter fertilizers under any NPK fertigation rates on leaf's P and K contents, in both experiments. The highest leaf's P content was achieved with soil application of SF2 (7-28-7 $\left.\mathrm{N}-\mathrm{P}_{2} \mathrm{O}_{5}-\mathrm{K}_{2} \mathrm{O} / \mathrm{ha}\right)+125 \%$ of NPK, in the two experiments. Therefore, the highest mean values of leaf's $\mathrm{K}$ content were attained from 75 or $125 \%$ of recommended NPK plus $\mathrm{SF}_{2}$, in the first and second experiment, respectively.

\subsection{Fruit Yield and Fruit Setting Percentage}

The results showed that increasing NPK fertigation rate was associated with significant increments in fruits yield 
weight, number of fruits per plant, average fruit weight and fruit setting (Table 8). The highest significant mean values of all above mentioned characters were resulting from the highest NPK fertigation rate $(125 \%$ of recommended), in both experiments. Concerning number of fruits per plant and fruit yield, the two NPK fertigation rates 100 and $125 \%$ of recommended appeared insignificant differ and gave significantly higher values than that estimated for the other rates of NPK.

Table 8. Effect of NPK fertigation rates and starter fertilizer on the fruit yield and fruit setting percentage of cucumber plant

\begin{tabular}{|c|c|c|c|c|c|c|c|c|c|}
\hline \multirow{2}{*}{\multicolumn{2}{|c|}{ Treatments* }} & \multicolumn{6}{|c|}{ Fruit yield characters } & \multirow{2}{*}{\multicolumn{2}{|c|}{ Fruits setting \% }} \\
\hline & & \multicolumn{2}{|c|}{ Yield per plant (kg) } & \multicolumn{2}{|c|}{ Fruits number per plant } & \multicolumn{2}{|c|}{ Fruit weight (g) } & & \\
\hline NPK \% & $\begin{array}{c}\text { Starter } \\
\text { fertilizer }\end{array}$ & $1^{\text {st }}$ Trial & $2^{\text {nd }}$ Trial & $1^{\text {st }}$ Trial & $2^{\text {nd }}$ Trial & $1^{\text {st }}$ Trial & $2^{\text {nd }}$ Trial & $1^{\text {st }}$ Trial & $2^{\text {nd }}$ Trial \\
\hline 50 & & $1.921 C^{* *}$ & $1.869 \mathrm{C}$ & $15.8 \mathrm{~B}$ & $15.2 \mathrm{~B}$ & $117.5 \mathrm{~B}$ & $113.7 \mathrm{C}$ & $46.4 \mathrm{D}$ & $43.9 \mathrm{D}$ \\
\hline 75 & & $2.572 \mathrm{~B}$ & 2.351B & $15.9 \mathrm{~B}$ & $16.1 \mathrm{~B}$ & 115.1B & 119.4B & $49.9 \mathrm{C}$ & $47.6 \mathrm{C}$ \\
\hline 100 & & $2.904 \mathrm{~A}$ & $2.731 \mathrm{~A}$ & $17.4 \mathrm{~A}$ & $18.0 \mathrm{~A}$ & $115.8 \mathrm{~B}$ & $121.2 \mathrm{~B}$ & $54.4 \mathrm{~B}$ & $51.5 \mathrm{~B}$ \\
\hline \multirow[t]{5}{*}{125} & & $3.094 \mathrm{~A}$ & $2.931 \mathrm{~A}$ & $18.3 \mathrm{~A}$ & $18.6 \mathrm{~A}$ & $122.2 \mathrm{~A}$ & $123.5 \mathrm{~A}$ & $58.4 \mathrm{~A}$ & $55.9 \mathrm{~A}$ \\
\hline & $\mathrm{SF}_{0}$ & $1.461 \mathrm{C}$ & $1.403 \mathrm{C}$ & $12.5 \mathrm{C}$ & $11.8 \mathrm{C}$ & $117.8 \mathrm{~A}$ & 118.4B & $54.1 \mathrm{~A}$ & $51.0 \mathrm{~A}$ \\
\hline & $\mathrm{SF}_{1}$ & $3.080 \mathrm{~B}$ & $2.731 \mathrm{~B}$ & $18.4 \mathrm{~B}$ & $18.6 \mathrm{~B}$ & $116.8 \mathrm{~B}$ & $122.1 \mathrm{~A}$ & $51.5 \mathrm{~B}$ & $51.0 \mathrm{~A}$ \\
\hline & $\mathrm{SF}_{2}$ & $3.327 \mathrm{~A}$ & $3.278 \mathrm{~A}$ & $19.7 \mathrm{~A}$ & $20.2 \mathrm{~A}$ & $118.3 \mathrm{~A}$ & $118.0 \mathrm{~B}$ & $51.2 \mathrm{~B}$ & $47.2 \mathrm{~B}$ \\
\hline & $\mathrm{SF}_{0}$ & $1.352 \mathrm{c}$ & $1.300 \mathrm{c}$ & $11.6 \mathrm{f}$ & $12.1 \mathrm{e}$ & $116.5 \mathrm{e}$ & $114.1 \mathrm{~g}$ & $43.0 \mathrm{~d}$ & $54.0 \mathrm{ab}$ \\
\hline \multirow[t]{3}{*}{50} & $\mathrm{SF}_{1}$ & $1.479 \mathrm{c}$ & $1.464 \mathrm{c}$ & $17.2 d$ & $16.2 d$ & $121.3 \mathrm{bc}$ & $116.6 \mathrm{f}$ & $45.8 \mathrm{~cd}$ & $35.8 \mathrm{c}$ \\
\hline & $\mathrm{SF}_{2}$ & $2.933 \mathrm{ab}$ & $2.844 \mathrm{ab}$ & $18.6 \mathrm{bcd}$ & $17.2 \mathrm{~cd}$ & $113.7 \mathrm{f}$ & $110.5 \mathrm{~h}$ & $50.4 \mathrm{bcd}$ & $42.0 \mathrm{bc}$ \\
\hline & $\mathrm{SF}_{0}$ & $1.387 \mathrm{c}$ & $1.498 \mathrm{c}$ & $12.5 \mathrm{ef}$ & $11.4 \mathrm{e}$ & $110.9 \mathrm{~g}$ & $107.4 \mathrm{i}$ & $58.3 \mathrm{ab}$ & $45.8 \mathrm{bc}$ \\
\hline \multirow[t]{3}{*}{75} & $\mathrm{SF}_{1}$ & $2.905 \mathrm{ab}$ & $2.269 \mathrm{~b}$ & $17.4 \mathrm{~d}$ & $18.6 \mathrm{bc}$ & $121.4 \mathrm{bc}$ & $130.7 \mathrm{a}$ & $42.4 \mathrm{~d}$ & $48.8 \mathrm{bc}$ \\
\hline & $\mathrm{SF}_{2}$ & $3.425 \mathrm{a}$ & $3.287 \mathrm{ab}$ & $17.7 \mathrm{~cd}$ & $18.3 \mathrm{bc}$ & $112.2 \mathrm{fg}$ & $120.0 \mathrm{de}$ & 49.0bcd & $48.3 b c$ \\
\hline & $\mathrm{SF}_{0}$ & $1.499 \mathrm{c}$ & $1.357 \mathrm{c}$ & $12.3 \mathrm{ef}$ & $11.9 \mathrm{e}$ & $121.9 \mathrm{~b}$ & $131.4 \mathrm{a}$ & $57.6 a b$ & $54.8 \mathrm{ab}$ \\
\hline \multirow[t]{3}{*}{100} & $\mathrm{SF}_{1}$ & $3.938 \mathrm{a}$ & $3.423 \mathrm{ab}$ & $19.8 \mathrm{~b}$ & $19.2 \mathrm{~b}$ & $104.2 \mathrm{~h}$ & $118.3 \mathrm{ef}$ & $55.5 \mathrm{ab}$ & $51.0 \mathrm{~b}$ \\
\hline & $\mathrm{SF}_{2}$ & $3.275 \mathrm{a}$ & $3.414 \mathrm{ab}$ & $20.1 b$ & $22.8 \mathrm{a}$ & $121.1 \mathrm{bc}$ & $113.9 \mathrm{~g}$ & $50.3 \mathrm{bcd}$ & $48.8 \mathrm{bc}$ \\
\hline & $\mathrm{SF}_{0}$ & $1.608 \mathrm{bc}$ & $1.458 \mathrm{c}$ & $13.4 \mathrm{e}$ & $12.1 \mathrm{e}$ & $119.9 \mathrm{~cd}$ & $120.5 \mathrm{~d}$ & $57.5 \mathrm{ab}$ & $49.6 \mathrm{bc}$ \\
\hline \multirow[t]{2}{*}{125} & $\mathrm{SF}_{1}$ & $3.999 \mathrm{a}$ & $3.768 \mathrm{a}$ & $19.3 b c$ & $21.4 \mathrm{a}$ & $118.8 \mathrm{~d}$ & $122.8 \mathrm{c}$ & $62.5 \mathrm{a}$ & $68.3 \mathrm{a}$ \\
\hline & $\mathrm{SF}_{2}$ & $3.676 \mathrm{a}$ & $3.567 \mathrm{a}$ & $22.2 \mathrm{a}$ & $22.3 \mathrm{a}$ & $126.9 \mathrm{a}$ & $127.4 \mathrm{~b}$ & $55.1 \mathrm{abc}$ & $49.9 \mathrm{bc}$ \\
\hline
\end{tabular}

"NPK treatments; $50,75,100$ and $125 \%$ of recommended; $220,150,150 \mathrm{~kg} \mathrm{~N}, \mathrm{P}_{2} \mathrm{O}_{5}, \mathrm{~K}_{2} \mathrm{O} /$ ha, respectively, starter fertilizer (SF); $\mathrm{SF}_{0}$ (control), $\mathrm{SF}_{1}: 7-14-7$ and $\mathrm{SF}_{2}: 7-28-7 \mathrm{~kg} \mathrm{~N}-\mathrm{P}_{2} \mathrm{O}_{5}-\mathrm{K}_{2} \mathrm{O} / \mathrm{ha}$.

${ }^{* *}$ Values having the same alphabetical letter in common, within a particular group of means in each character, do not significantly differ, using the revised LSD test at $\mathrm{P}<0.05$.

Data in Table 8, showed that soil application of $\mathrm{SF}_{2}\left(7-28-7 \mathrm{~N}-\mathrm{P}_{2} \mathrm{O}_{5}-\mathrm{K}_{2} \mathrm{O} /\right.$ ha) was accompanied by significant increases in fruit yield characters of cucumber expressed by the fruit yield and number of fruits per plant, in both experiments as well as achieved a significantly reduction in fruit setting percentage, in both experiments.

Concerning the interaction effect between NPK fertigation rates and starter fertilizers, the results showed that at any NPK fertigation rates, soil application of starter fertilizers produced significantly higher fruit yield and fruits number per plant compared with control treatment. Application of $\mathrm{SF}_{1}\left(7-14-7 \mathrm{~N}-\mathrm{P}_{2} \mathrm{O}_{5}-\mathrm{K}_{2} \mathrm{O}\right)$ combined with 125 $\%$ of NPK recommended resulted in the highest significant mean values for the number fruits per plant. However, the application of $\mathrm{SF}_{2}\left(7-28-7 \mathrm{~N}-\mathrm{P}_{2} \mathrm{O}_{5}-\mathrm{K}_{2} \mathrm{O}\right)+125 \%$ of recommended NPK gave the highest fruit yield per plant, in both experiments as well as the highest fruit weight, in the first experiment only. The highest increment in fruit setting percentage was noticed with the highest NPK fertigation rate $\left(125 \%\right.$ of recommended) $+\mathrm{SF}_{1}(7-14-7$ 
N-P $\mathrm{P}_{2} \mathrm{O}_{5}-\mathrm{K}_{2} \mathrm{O} /$ ha). However, application $100 \%$ of recommended NPK + SF rates was associated with significant decreases in fruit setting percentage, in two experiments.

\section{Discussion}

Application of NPK fertigation up rate $125 \%$ of recommended resulted in significant increases in the plant height and number of leaves at 30,50 and 70 DAS (Table 4 and 5), number of branches at 30 DAS only (Table 6), addition, increases in leaf's minerals (N, P and K) contents (Table 7), the fruit yield, number of fruits per plant fruit weight and fruit setting percentage (Table 8). This can be explained on the basis that fertigation saves fertilizer nutrients as it permits applying for fertilizer in small quantity at a time matching with the plants nutrient need. This contributes to an improved availability of moisture, nutrients, and uniform distribution of fertigated nutrients in the crop root zone throughout the growth stages leading to better uptake of nutrients. The enhancing effects of NPK on vegetative growth might be attributed to their vital contribution in several metabolic process in plants related to growth (Marschner, 1995). Moreover, to their role in increasing meristemic activities and its importance in the metabolism of many constituents such as amino acids, chlolophyll, auxins enzymes and general protein synthesis (Thompson \& Troeh, 1978). Stimulates not only photosynthesis but also many metabolic intermediates synthesis, this is decided by (Goh \& Haynes, 1986; Salisbury \& Ross, 1991), consequently stimulating the vegetative growth through prompt the plants to generate leaves, which are able to produce photosynthetic products accumulation required for fruits formation and development and subsequently fruit yield components. It was obvious that increasing yield potential was achieved at the expense of number of fruits per plant rather than average fruit weight. These results are in accordance with those obtained by (Rubeiz, 1990; Choudhari \& More, 2002; Jilani et al., 2009) they found that increasing NPK levels have an important role in enhancing the vegetative growth of cucumber plant. Rehamn et al. (1995) and Jilani et al. (2009) who found that NPK at rate $140-60-150 \mathrm{~kg} /$ ha showed better results for more fruits per vine, maximum fruit weight, vine length and total yield. Therefore, Eifediyi and Remison (2009) indicated that the number of fruits per plant, fruit weight per plant, fruit number per plant and total yield per hectare were increased significantly with increase NPK fertilizer application up to $400 \mathrm{~kg} / \mathrm{ha}$.

Cucumber plants receiving starter fertilizers achieved an increase in the plant height, number of leaves and branches (Tables 4-6), especially at early growth stages (30 and 50 DAS) and fresh weight of root and stem, in two experiments. Soil application of SF2 (7-28-7 N-P $\left.\mathrm{P}_{2} \mathrm{O}_{5}-\mathrm{K}_{2} \mathrm{O} / \mathrm{ha}\right)$ was accompanied by significant increases in fruit yield characters as well as significantly reduction in fruit setting percentage (Table 8 ). This can be described based on starter solutions rich in P used as a drench to the seedling root area accelerated root development and increasing the plant's ability to absorb more nutrients from the soil that could encourage the vegetative growth, accelerate the photosynthetic rate, increasing the meristematic activity and building protein molecules (Marschner, 1995; Asian vegetable research and development center, 1999-2004). Ma and Kalb (2006) stated that starter solution effect on plant growth was extremely significant and mostly occurred between one and seven weeks after transplanting, but was not significant at 8 and 9 weeks after transplanting, as clear for leaves and branches number characters at 70DAS (Tables 5 and 6). Similarly, Stone $(1998,2000)$ showed that good response to the establishment and early growth in some vegetable crops with soil application of starter fertilizer. Feleafel and Mirdad (2014) exhibited that tomato plants receiving SS4 (100-400-100 (1:4:1) mg/L of N$\mathrm{P}_{2} \mathrm{O}_{5}-\mathrm{K}_{2} \mathrm{O}$ recorded maximum plant height; at 6,8 and 10 weeks after transplanting (WAT), and leaves number; at 6 and 8 WAT.

The interaction effect between NPK fertigation rate and starter fertilizer showed that cucumber plants receiving NPK fertigation up rate $125 \%+$ SF had the highest mean values of the some vegetative growth characters; plant height at all growth stages and number of leaf and branches at 30 DAS. Application of SF1 (7-14-7 N- $\left.\mathrm{P}_{2} \mathrm{O}_{5}-\mathrm{K}_{2} \mathrm{O}\right)$ $+125 \%$ of recommended NPK resulted in the highest significant mean values for the fruit setting percentage, number fruits per plant. However, the application of SF2 (7-28-7 N-P $\left.\mathrm{P}_{2} \mathrm{O}_{5}-\mathrm{K}_{2} \mathrm{O}\right)+125 \%$ of recommended NPK gave the highest fruit yield per plant. This two-factor interactive indicated that fertigated nutrients remained concentrated near the point of application and thus helped in improved nutrient availability in the root zone and increased vegetative growth and then fruit yield characteristics. These results are in accordance with those obtained by Stone (2000) who found that starter fertilizer in combination with lowed rates of supplementary $\mathrm{N}$ gave yields comparable with higher rates of base $\mathrm{N}$ with each crop of bulb onion, crisp lettuce, forage maize, except sugar beet. Ma and Kalb (2006) found that effects of starter solution combined with organic fertilizers were generally more obvious than an application with inorganic basal fertilizers. The studies of AVRDC (1999-2004) indicated that starter solutions might promote an increased uptake of nutrients from organic fertilizers.

In conclusion, the most efficient combination treatment is soil application of starter fertilizers, one week after 
seeding with fertigation NPK at rate $125 \%$ of recommended, at two doses weekly from $2^{\text {nd }}$ week to $14^{\text {th }}$ week after seeding, which gave the best results for growth and yield characters of cucumber grown under greenhouse.

\section{References}

Abdel-Aziz, A. A. (1998). Evaluation of some modern chemigation techniques. Ph.D. Thesis, Faculty of Agriculture, Ain Shams University, Egypt.

Allen, R. G., Pereira, L. S., Raes, D., \& Smith, M. (1998). Crop Evapotranspiration-Guidelines for Computing Crop Water Requirements (pp. 104-114). FAO Irrigation and drainage paper No. 56. FAO Rome, Italy.

AVRDC. (1999-2004). Progress Reports 1998-2003. Asian Vegetable Research and Development Center, Shanhua, Taiwan.

Bricker, B. (1991). MSTAT-C. A micro computer program from the design management and analysis of agronomic research experiments. Michigan State University.

Choudhari, S. M., \& More, T. A. (2002). Fertigation, fertilizer and spacing requirement of Tropical gynoecious cucumber hybrids. ISHS. Tsukuba, Japan. Acta Hort., 61, 588.

Cottenie, A. (1980). Soil and Plant Testing as a Basis of Fertilizer Recommendations (pp. 55-60). FAO soil Bulletin. Soil Resources, Management and Conservation Service No. 38/2. FAO Rome, Italy.

Dufault, R. J., \& Schulthesis, J. R. (1994). Bell pepper seedling growth and yield following pre-transplant nutritional conditioning. HortScience, 29, 999-1007.

Eifediyi, E. K., \& Remison, S. U. (2010). Growth and yield of cucumber (Cucumis sativum L.) as influenced by farm yard manure and inorganic fertilizer. Journal of Plant Breeding and Crop Science, 2, 216-220.

Elkner, K., \& Radzikowska, D. (1976). Influence of irrigation, mineral nutrition and variety on the pickling quality of cucumber. Zeszyty- Problemowe- Postepow- Nauk- Rolniczych, 181, 55-70.

Feleafel, M. N., \& Mirdad, Z. M. (2013). Optimizing the nitrogen, phosphorus and potash fertigation rates and frequency for eggplant in arid regions. Int. J. Agric. Biol., 15, 737-742.

Feleafel, M. N., \& Mirdad, Z. M. (2014). Alleviating the deleterious effects of water salinity on greenhouse grown tomato. Int. J. Agric. Biol., 16, 49-56.

Fischer, A., \& Richter, C. (1984). Influence of organic and mineral fertilizers on yield and quality of potatoes (p. 37). The Fifth IFOAM International Scientific Conference at the University of Kassel, Germany.

Goh, K. M., \& Haynes, R. J. (1986). Nitrogen and agronomic practice. In R. J. Haynes (Ed.), Mineral $N$ in the plant soil system (pp. 379-442). Academic Press Inc., Orlando, Harcourt, UK.

Jilani, M. S., Bakar, A., Waseem, K., \& Kiran, M. (2009). Effect of different levels of NPK on the growth and yield of cucumber (Cucumis sativus) under the plastic tunnel. J. Agric. Soc. Sci., 5, 99-101.

Jokela, W. E. (1992). Effect of starter fertilizer on corn silage yields on medium and high fertility soils. J. Prod. Agric., 5, 233-237. http://dx.doi.org/10.2134/jpa1992.0233

Kohzushka, L. F., \& Romanets, V. (1994). Ecological and economic efficiency of mineral fertilizer application as a component of irrigation water. 17th ICID European Regional Conference on Irrigation and Drainage, May 16-22, pp. 209-213.

Ma, C. H., \& Kalb, T. (2006). Development of starter solution technology as a balanced fertilization practice in vegetable production. In F. Tei, P. Benincasa \& M. Guiducci (Eds.), Towards Ecologically Sound Fertilization Strategies for Field Vegetable Production. Int. Seminar Proc. Acta Hort., 700, 167-172.

Mahdi, S. S., Hassan, G. I., Samoon, S. A., Rather, H. A., Dar, S. A., \& Zehra, B. (2010). Bio-fertilizers in organic agriculture. J. Phytol., 2, 42-54.

Marschner, H. (1986). Mineral nutrition of higher plants. San Diego, California: Academic Press.

Marschner, H. (1995). Mineral nutrition of higher plants (2nd ed., p. 864). Acad Press Limited, Text Book.

Mikkelsen, R. L. (1989). Phosphorus fertilization through drip irrigation. J. Prod. Agric., 2, 279-286. http://dx.doi.org/10.2134/jpa1989.0279

Miller, R. J., Rolstan, D. E., Rauschkolb, R. S., \& Walfe, D. W. (1976). Drip irrigation of nitrogen is efficient. Calif. Agric., 30, 16-18.

Nova, R., \& Loomis, R. S. (1981). Nitrogen and plant production. Plant and soil, 58, 177-204. 
http://dx.doi.org/10.1007/BF02180053

Page, A. L., Miller, R. H., \& Reeney, D. R. (1982). Methods of Soil Analysis, Part 2. ASA, SSSA, Madison, Wisconsin, USA.

Qasim, M., Ahmad, I., \& Ahmad, T. (2008). Optimizing fertigation frequency for Rosa hybrid. Pak. J. Bot., 40, 533-545.

Qassim, A., \& Ashcroft, B. (2002). Estimating vegetable crop water use with moisture-accounting method \# AG1192, DPI Victoria. http://www.dpi.vic.gov.au/agriculture/horticulture/vegetables/vegetable-growing-and-management/estimati ng-vegetable-crop-water-use

Razmi, Z., \& Ghaemi, A. A. (2011). Crop and soil water stress coefficients of tomato in the glass greenhouse conditions. J. Sci. Technol. Greenhouse Culture, 2, 87.

Rubeiz, I. G. (1990). Response of greenhouse cucumber to mineral fertilizers on a high phosphorus and potassium soil. J. Plant Nutr., 13, 269-273. http://dx.doi.org/10.1080/01904169009364072

Salisbury, F. B., \& Ross, C. W. (1991). Plant Physiology. $4^{\text {th }}$ Edition. Wadsworth, Belmont, California. 540.

Stone, D. A. (1998). The effect of «starter» fertilizer injection on the growth and yield of drilled vegetable crops in relation to soil nutrient status. J. Hort. Science \& Biotech, 73, 441-451. http://dx.doi.org/10.1111/j.1475-2743.2000.tb00212.x

Stone, D. A. (2000). Nitrogen requirement of wide-spaced row crops in the presence of starter fertilizer. Soil Use and Management, 16, 285-292.

Thompson, L., M., \& Troeh, F. R. (1978). Soils and soil fertility (p. 516). MeGraw. New York: Hill Book company.

\section{Copyrights}

Copyright for this article is retained by the author(s), with first publication rights granted to the journal.

This is an open-access article distributed under the terms and conditions of the Creative Commons Attribution license (http://creativecommons.org/licenses/by/3.0/). 